\title{
Satellite and ship studies of phytoplankton in the Northeastern Arabian during 2000 - 2006 period
}

\author{
S. G. Prabhu Matondkar*a, R.M. Dwivedi ${ }^{\mathrm{b}}$, Sushma Parab ${ }^{\mathrm{a}}$, Suraksha Pednekar ${ }^{\mathrm{a}}$, E. S. Desa ${ }^{\mathrm{a}}$, \\ A. Mascarenhas ${ }^{a}$, Mini Raman ${ }^{b}$ and S. K. Singh ${ }^{b}$ \\ ${ }^{a}$ National Institute of Oceanography, Goa, INDIA 403004 \\ ${ }^{\mathrm{b}}$ Space Application Centre, Ahmedabad, Gujarat, INDIA
}

\begin{abstract}
Sequence of the images from IRS P4 / OCM satellite and extensive shipboard sampling programme are used to understand the seasonal variation of phytoplankton abundance and types in the Northeastern (NE) Arabian Sea and Lakshadweep Sea. An appreciable degree of spatial and temporal variability is observed in chlorophyll a distribution from November to April months, as well as coastal and offshore stations, indicating marked seasonality in phytoplankton distribution in NE Arabian Sea. During November month (fall intermonsoon) average chlorophyll $a$ (Chl $a$ ) by fluorometer was $\left(0.799 \mathrm{mgm}^{-3}\right)$ and by OCM it was $0.584 \mathrm{mgm}^{-3}$. The higher chlorophyll $a$ observed was due to Trichodesmium (cyanobacteria) blooms. During December the average chlorophyll a was $0.34 \mathrm{mgm}^{-3}$ also due to Trichodesmium filaments in water column. During January onwards winter cooling led to increase in nutrients which enhanced chlorophyll $a$ value to $0.64 \mathrm{mgm}^{-3} \mathrm{due}$ to growth of flagellates (as seen by high chlorophyll $b$ besides chlorophyll $a$ ) in water column. February, March and April supported moderately high chlorophyll value (0. 3 to 0.5 $\mathrm{mgm}^{-3}$ ) due to growth of prasinophytes (as seen by pigment prasinoxanthin) and blooms of the Noctiluca miliaris. Time series monitoring of Noctiluca bloom was also conducted using OCM based chlorophyll images in NE Arabian Sea. During February chlorophyll $a$ retrieved by OCM was 0.3 to $0.9 \mathrm{mgm}^{-3}$. Pigment analysis of water samples indicated the equal important of accessory pigment like zeaxanthin, prasinoxanthin, $\beta$-carotene. The relevance of these pigments estimated by HPLC like zeaxanthin (cyanobacteria), fucoxanthin (diatoms), peridinin (dinoflagellates) is presented and discussed. Similarly, exercise is conducted in Lakshadweep waters where Trichodesmium related peak in chlorophyll $a$ was observed during March onwards in OCM data. The average chlorophyll $a$ in NE Arabian Sea at surface during November was $\left(0.726 \mathrm{mgm}^{-3}\right)$, December $\left(0.34 \mathrm{mgm}^{-3}\right)$, January $\left(0.723 \mathrm{mgm}^{-3}\right)$, February $\left(0.344 \mathrm{mgm}^{-3}\right)$, March $(0.963$ $\mathrm{mgm}^{-3}$ ) and April $0.665 \mathrm{mgm}^{-3}$. Similar trend was observed in primary productivity estimates. The attempt is made to work out seasonality in the productivity of the Arabian Sea using OCM derived chlorophyll and relation of enhancement in productivity due to development of winter blooms in the Arabian Sea. The environmental conditions (temperature, wind, nutrients and mixed layer depth) affecting these blooms responsible for year to year variation in bloom biomass and productivity is also presented in detail.
\end{abstract}

Keywords: HPLC, phytoplankton, ocean colour monitor, Arabian Sea, chlorophyll

\section{INTRODUCTION}

The reversal of monsoon winds brings about changes in circulation pattern of the Arabian Sea ${ }^{1,2,3}$ have shown that this reversal winds can induce seasonality in the abundance of phytoplankton in the Arabian Sea and winter blooms ${ }^{4}$. The seasonality of phytoplankton is also connected to coastal

*sgpm@nio.org; phone +91 (0832) 2450233; fax 91 (0832) 2450606

Remote Sensing of the Marine Environment, edited by Robert J. Frouin, Vijay K. Agarwal,

Hiroshi Kawamura, Shailesh Nayak, Delu Pan, Proc. of SPIE Vol. 6406, 64061I, (2006)

0277-786X/06/\$15 - doi: 10.1117/12.693693

Proc. of SPIE Vol. 6406 64061I-1 
processes related to monsoons ${ }^{5,6}$. During southwest monsoon (June-September), west coast of India experience upwelling of nutrient rich water. During this period there is a southwardly movement of surface currents and shallowing of isotherms along the coast. Towards the end of the SW monsoon offshore component of wind stress receds so is upwelling. During NE monsoon (November-March), the surface currents reverse their direction and move northwards along the coast carrying warm, low saline, low nutrient waters from equatorial region. During this time thermoclines are located in deeper part of water column. In the region north of $15^{\circ} \mathrm{N}$ this northward flowing current turns westwards off the coast of Saurashtra. These environmental changes decide the phytoplankton seasonality in the Arabian Sea along the west coast of India. Since the early 1940s the method of choice for studying phytoplankton diversity has been ${ }^{7-14}$. Although the data sets obtained have provided valuable insights into the diversity of phytoplankton, such information has been limited to regions very close to the coast.

In addition to microscopy, photosynthetic and non-photosynthetic pigment distributions was used to identify the presence of different algal groups ${ }^{15-17}$. Accessory pigments can provide class-specific differentiation, allowing for the recognition of major taxonomic groups of marine phytoplankton ${ }^{15}$. Over the last twenty years, the development of high performance liquid chromatography (HPLC) has greatly advanced our understanding of phytoplankton pigment composition and functionality in response to ecosystem changes ${ }^{15,18}$. In the western and central Arabian Sea for example, HPLC-analyzed pigments helped provide new information as well as a better understanding of changes in phytoplankton populations associated with the seasonal cycle of the monsoons ${ }^{19,20,21}$.

During this study a wide and varied sampling strategy offshore as well as close to the coast ensured a comprehensive investigation on the seasonality of phytoplankton during the SW monsoon (June-August) when upwelling occurs along the west coast of India ${ }^{5}$, during the NE monsoon (November - February) when winter cooling takes place $\mathrm{e}^{22-25}$ and during the inter-monsoon (March-May) when the water column becomes highly stratified and devoid of nutrients ${ }^{26}$. Chlorophyll and primary productivity studies are also conducted during this study. Besides shipboard data IRS-P4 (OCM) data from the Arabian Sea is also collected for strengthening the idea of phytoplankton seasonality in the Arabian Sea

\section{METHODOLOGY}

Data on phytoplankton taxonomy, pigments and primary productivity is collected from NE Arabian Sea during NovApril months. Station positions during various cruises is presented in Fig. 1.

2.1 Physico-chemical study: Temperature and salinity data was collected by using CTD. Nutrients like $\mathrm{PO}_{4}-\mathrm{P}_{\text {and }} \mathrm{NO}_{3}$ $\mathrm{N}$ are analysed by using standard methods ${ }^{27}$.

2.2 Biological studies: Water was collected within the euphotic zone with 5L Niskin sampling bottles mounted onto a Sea Bird Electronics ${ }^{\circledR}$ CTD Rosette and processes in ship laboratory for pigments, primary productivity and taxonomy of the phytoplankton. The depth of the euphotic zone was established using a Secchi Disc.

\subsubsection{Chl a by Fluorometer}

Phytoplankton Chl $a$ concentration was determined by filtering $1000 \mathrm{ml}$ of seawater in $10 \mathrm{ml}$ of $90 \%$ acetone, sonicated and held in the dark in a freezer overnight. Chl a concentration was determined with a Turner designs 10-000R fluorometer (UNESCO, 1994). The fluorometer was periodically calibrated with a spectrophotometer according to UNESCO, 1994.

\subsubsection{Pigments by HPLC method}

For pigment estimations, samples between 1 and 2.5 litre were filtered through GF/F filters, frozen in liquid nitrogen at sea and then transported to the shore lab for analysis by HPLC $^{15,17}$. Prior to the HPLC analysis, the filters were immersed in $90 \%$ acetone, extracted under cold and dark conditions overnight, sonicated and finally filtered through $0.2 \mu \mathrm{m}, 13$ $\mathrm{mm}$ PTFE filters to rid the sample of particulate debris. Aliquots of $1 \mathrm{ml}$ of the pigment extract was then mixed with 0.3 $\mathrm{ml}$ of distilled water in a $2 \mathrm{ml}$ amber vial and allowed to equilibrate for 5 minutes prior to injection into an HPLC (Agilent ${ }^{\circledR} 1100$ series) equipped with a diode array detector. The mobile phase was a gradient mixture of 3 solvents: Solvent A (80:20, v:v; methanol : 0.5M ammonium acetate aq., $\mathrm{pH}=7.2 ; 0.01 \%$ BHT, w:v), Solvent B (87.5:12.5,v:v; acetonitrile : water; $0.01 \%$ BHT, w:v ) and Solvent C (ethyl acetate). Pigments were separated in a C-18 reverse-phase column using the eluent gradient program of Wright, et al. (1991) as adapted by Bidigare and Charles (2002). Chl, 
carotenoids and xanthophylls were detected by their absorbance peaks at $436 \mathrm{~nm}$ and identified by comparison with the retention times of standard pigments obtained from DHI ${ }^{\circledR}$ Water and Environment, Denmark, and Sigma Aldrich Chemicals ${ }^{\circledR}$ USA.

\subsubsection{Primary Productivity}

Water samples were collected and estimated by ${ }^{14} \mathrm{C}$ technique and insitu incuabations where activity was determined with a Wallac Scintillation counter (model no. 1409). All counts were quench corrected ${ }^{28}$.

\subsubsection{Phytoplankton Taxonomy}

For identification and enumeration of phytoplankton, $1000 \mathrm{ml}$ of seawater samples was fixed with $3 \%$ Lugol's iodine ${ }^{29}$ and then stored in dark and cool conditions until the time of analysis. Prior to microscopic analysis, samples were concentrated to $5-10 \mathrm{ml}$ by carefully siphoning the top layer with a tube covered with a $10 \mu \mathrm{m}$ Nytex filter on one end. Replicates of $1 \mathrm{ml}$ sample concentrates were transferred to a Sedgwick-Rafter and counted using an Olympus Inverted microscope (Model IX 50) at $200 \mathrm{X}$ magnification. Identifications were based on standard taxonomic keys $\mathrm{s}^{30}$. The results are expressed as numbers of cells except for Trichodesmium which are expressed as number of trichomes.

\subsection{OCM data}

\subsubsection{Estimation of chlorophyll from Oceansat I / OCM}

As a part of processing of OCM data to generate chlorophyll images water leaving radiances were retrieved through removal of atmospheric effects from the satellite radiance values in the first step ${ }^{31}$. The atmospheric correction scheme makes use of long wavelengths for estimating aerosol optical thickness. Subsequently, bio-optical algorithm was applied to the corrected water leaving radiance data ${ }^{32,33}$. O'Reilly's OC-2 algorithm was used for generating chlorophyll images from OCM data.

\section{RESULTS AND DISCUSSION}

Phytoplankton counts at surface and column as well as group level information at surface is presented in Table 1. During November cyanobacteria constituted major phytoplankton population $(69.21 \%)$. The average surface counts were high $15.831 \times 10^{4} \mathrm{~L}^{-1}$ so was column counts of phytoplankton during November $\left(180.69 \times 10^{6} \mathrm{~m}^{-2}\right)$. The high counts of Trichodesmium were also recorded in column during December although surface counts were low. January and February counts were moderately high in water column was mainly due to Noctiluca bloom in the water column. The high phytoplankton counts during March and April was again high due to Trichodesmium bloom. During April as high as 80 $\%$ phytoplankton were composed of the Trichodesmium spp. specially Trichodesmium erythraeum. The Chl $a$ estimated during various months is presented in Table 2. Chl $a$ was high during November (due to cyanobacteria), February (due to Noctiluca) and April to May due to Trichodesmium erythraeum. Similar trend was observed in the column Chl $a$. The high value was due to Trichodesmium erythraeum bloom during Nov, Noctiluca bloom during February and T. erythraeum blooms during April and May (plates) which is discussed below.

\subsection{Fall Intermonsoon season (November)}

During November high Chl $a$ at surface $\left(0.726 \mathrm{mgm}^{-3}\right)$ and column $\left(43.812 \mathrm{mgm}^{-2}\right)$ is due to Trichodesmium thiebautii bloom. The bloom of $T$. thiebautii during November was also seen under ocean colour image of November. The productivity of area was comparatively low at surface $\left(8.46 \mathrm{mgCm}^{-3} \mathrm{~d}^{-1}\right)$ as well as column $\left(21.139 \mathrm{mgCm}^{-3} \mathrm{~d}^{-1}\right)$ and is mainly due to shortage of nitrogen nutrients as indicated by Trichodesmium growth in the environment. The presence of Trichodesmium was also noticed in the pigment analysis. During November zeaxanthin and $\beta$-carotene level in particulate matter is high. The environmental conditions during November favoured the Trichodesmium growth. NE Arabian Sea, wind was low and PAR was high. This combined with low nitrate level was responsible for growth of the Trichodesmium during November (fall intermonsoon) in the Arabian Sea. 


\subsection{NE Monsoon ( December to February )}

The NE monsoon season is responsible for the churning of the water column through nutrients like $\mathrm{NO}_{3}$ and $\mathrm{PO}_{4}$ level was high during NE monsoon, unstability of water column was responsible for maintaining Chl $a$ to moderately high level. Chl $a$ during December was $0.34 \mathrm{mgm}^{-3}$, January $0.723 \mathrm{mgm}^{-3}$ and February $0.344 \mathrm{mgm}^{-3}$. During January increase in Chl $a$ was due to high counts of dinoflagellates in water column. This peak in dinoflagellates has helped to promote growth of the Noctiluca miliaris during January and February. Similar trend of the Chl $a$ was also observed by OCM images (Fig. 3). The column Chl $a$ values were maximum during January (44.524 $\mathrm{mgm}^{-2}$ ) compared to December and February (Table 1). The rate of primary productivity was high during December and January but low during February (Table 2). The Noctiluca miliaris is the heterotrophic dinoflagellates and same productivity recorded was due to symbiotic algae (prasinophytes) inside Noctiluca miliaris cells.

\subsection{Spring Intermonsoon (March to April)}

The hike in Chl $a$ (surface and column) was recorded during March-April, due to blooms of the T. erythraeum. This has increased primary productivity at surface as well as in column. During this period (spring intermonsoon) water temperature was high, nutrients were low which help to develop T. erythraeum bloom in the NE Arabian Sea. The chemotaxonomic studies during January revealed the presence of peridinin indicating the growth of dinoflagellates prior to Noctiluca. During Noctiluca bloom Chl $b$ at high level so was prasinoxanthin due to symbiotic prasinophytes. During spring intermonsoon the high levels of the zeaxanthin and $\beta$-carotene was indicative of the Trichodesmium in the NE Arabian Sea specially during April. In the May, zeaxanthin was $11.77 \%, \beta$-carotene was $8 \%$ due to extensive bloom of the Trichodesmium in the Arabian Sea specially in coastal region.

\section{CONCLUSIONS}

In Nov/Dec, depletion of nutrients upwelled during SW monsoon coincided with development of blooms of T. thiebautii at surface in Nov and at subsurface in Dec. This was confirmed by elevated zeaxanthin and $\beta$-carotene measured. Low Chl $a$ concentrations and low phytoplankton counts were seen in Dec, a situation that was mirrored in the ocean colour images. In Jan, blooms comprising of a mixture of several species of dinoflagellates were observed which contributed to the high Chl $a$ seen in the ocean color data and to the high concentrations of peridinin measured by HPLC. This mixed dinoflagellate bloom was followed by an intense N. miliaris bloom in Feb. The elevated levels of Chl $b$ and Chl $c$ were derived from the $N$. miliaris bloom. High levels of prasinoxanthin were due to the symbiotic prasinophyte Pedinomonas noctilucae that the $N$. miliaris harbors as an endosymbiont. T. erythraeum blooms were seen in association with the $N$. miliaris bloom as well as during the post $N$. miliaris bloom stage in Mar-April. May was marked by an intense $T$. bloom which was associated with flagellates as the associated phytoplankton.

\section{Acknowledgment:}

We appreciate the encouragement and support of Director, NIO Dr. S. R. Shetye for conducting this work. This study was carried out under the Ocean Colour Project with financial assistance from Space Application Centre (SAC), Ahmedabad. A SAC Fellowship to S. G. Parab and S. Pednekar is gratefully acknowledged. 


\section{REFERENCES}

1. K. Wyrtki, "Phyical Oceanography of the Indian Ocean", The Biology of the Indian Ocean, B. Zietzschel and Geralache, 18-36, Chapman-Hall, London, 1973.

2. K. Banse, "Overview of the hydrography and associated biological phenomena in the Arabian Sea, Off Pakistan", Marine geology and oceanography of Arabian Sea and coastal Pakistan, B. H.Haq and J. D. Milliman, 217-303, Van Nostrand Reinhold, New York, 1984.

3. K. Banse, "Seasonality of phytoplankton chlorophyll in the central and northern Arabian Sea", Deep-Sea Res., 34, 713-723, 1987.

4. R. M. Dwivedi, M. Raman, S. Parab, S. G. Prabhu Matonkdar, S. Nayak, "Influence of northeasterly trade winds on intensity of winter bloom in the Northern Arabian Sea", Current Science, 90, 1397 - 1406, 2006.

5. S. R. Shetye, A. D. Gouveia, S.S.C. Shenoi, D. Sounder, G. S. Michael, A.M. Almeida, K. Santanam, "Hydrography and circulation off the west coast of India during the Southwest Monsoon 1987, Journal of Marine Research, 48, 359-378, 1990.

6. S. R. Shetye, "Propagation of tides in the Mandovi and Zuari esturies", Sadhana, 24, 5-16, 1999.

7. C. C John, M. A. S. Menon, "Food and feeding habits of the oil sardine and mackerel", Current Science, 11, 243-244, 1942.

8. R. Subrahmanyan, "Studies on the phytoplankton of the west coast of India" I. Quantitative and qualitative fluctuation of the total phytoplankton crop, the zooplankton crop and their relationship, with remarks on the magnitude of the standing crop and production of matter and their relationship to fish landings, B50, 113-187, Proceedings Indian Academy of Sciences (Biological Science), 1959.

9. R. Subrahmanyan, A. H. V. Sarma, "Studies on the phytoplankton of the west coast of India Part III seasonal variation of the phytoplankton and environmental factors" Indian Journal of Fisheries, 7, 307 - 336, 1961.

10. R. Subrahmanyan, A. H. V. Sarma, "Studies on the phytoplankton of the west coast of India Part IV, magnitude of the standing crop for 1955-1962, with observations on nanoplankton and its significance to fisheries", Journal of the Marine Biological Association of India, 7, 406 - 419, 1967.

11. V. P. Devassy, P. M. A Bhattathiri, S. Z. Qasim, "Trichodesmium phenomenon", Indian Journal of Marine Sciences, 7, 168-186, 1978.

12. V. P. Devassy, P. M. A Bhattathiri, S. Z. Qasim, "Succession of organisms following Trichodesmium phenomenon", Indian Journal Marine Science, 8, 89-93, 1979.

13. V. P. Devassy, J. I. Goes, "Phytoplankton community structure and succession in a tropical estuarine complex (Central west co ast of India)", Estuarine Coastal and Shelf Science, 27, 671-685, 1988.

14. S. Sawant, M. Madhupratap, "Seasonality and composition of phytoplankton in the Arabian Sea", Current Science, 17, $869-873,1996$.

15. S.W. Wright, S. W. Jeffrey, R. G. C. Mantoura, C. A. Llewellyn, D. R. Bjornland, N. Welschmeyer, "Improved HPLC method for the analysis of chlorophylls and carotenoids from marine phytoplankton", Marine Ecology Progress Series, 77, 183-196, 1991.

16. S. W. Jeffrey, "Application of pigment methods to oceanography", Phytoplankton pigments in oceanography guidelines to modern methods, S. W. Jeffrey, S.W. Wright, 127-166, United Nations Educational, Scientific and Cultural Organization, Paris, 1997.

17. R. G. Bidigare, C. T. Charles, "HPLC phytoplankton pigments: sampling, laboratory methods and quality assurance procedures" Protocols For Satellite Ocean Colour Validation Revision 2, G. S. Fargion, J. L. Muellier, 154 - 160, NASA, Goddard Space Flight Centre, Greenbelt, Maryland 20771, 2002.

18. R. G. Barlow, R. F. C. Mantoura, D. G. Cummings, "Monsoonal influence on the distribution of phytoplankton pigments in the Arabian Sea", Deep-Sea Research II, 46, 677-699, 1999.

19. M. Latasa, R. Bidigare, "A comparison of phytoplankton populations of the Arabian Sea during the Spring Intermonsoon and Southwest Monsoon of 1995 as described by HPLC-analyzed pigments", Deep-Sea Research II 45, $2133-2170,1998$.

20. R. Goericke, "Top-down control of phytoplankton biomass and community structure in the monsoonal Arabian Sea" Limnology and Oceanography, 47, 1307-1323, 2002. 
21. S. L. Brown, M. R. Landry, S. Christensen, D. Garrison, M. M. Gowing, R. R. Bidigare, L. Campbell, "Microbial community dynamics and taxon-specific phytoplankton production in the Arabian Sea during the 1995 monsoon seasons", Deep-Sea Research II, 49, 2345 - 2376, 2002.

22. K. Banse, D. C. English, "Revision of satellite-based phytoplankton pigment data from the Arabian Sea during the northeast monsoon", Marine Research I (Pakistan), 2, 83 - 101, 1993.

23. K. Banse, D. C. English, "Geographical differences in seasonality of CZCS-derived phytoplankton pigment in the Arabian Sea for 1978 - 1986”, Deep-Sea Research II, 47, 1623 - 1677, 2000.

24. M. Madhupratap, S. Prasanna Kumar, P. M. A. Bhattathiri, M. Dileep Kumar, S. Raghukumar, K. K. C. Nair, N. Ramaiah, "Mechanism of the biological response to winter cooling in the northeastern Arabian Sea". Nature, 384, 549-552, 1996.

25. S. Prasanna Kumar, N. Ramaiah, M. Gauns, V. V. S. Sarma, P. M. Muraleedharan, S. Raghukumar, M. Dileep Kumar, M. Madhupratap, "Physical forcing of biological productivity in the Northern Arabian Sea during the Northeast Monsoon" Deep-Sea Research II, 48, 1115-1126, 2001.

26. S. N. DeSouza, M. Dileep Kumar, M., S.V. Sardessai, V. V. S. Sarma, P. V. Shirodkar, "Seasonal variability in oxygen and nutrients in the central and eastern Arabian Sea" Current Science, 71, 857-862, 1996.

27. K. Grasshoff, M. Ehrhardt, K. Krembling, Methods of seawater analysis, 419, Verlag Chemie, New York, NY, 1983.

28. UNESCO, "Protocols for the Joint Global Ocean Flux Study (JGOFS) core measurements", Manual and guides, 170, Scientific Committee on Oceanic Research, 29, 1994.

29. J. Throndsen, "Preservation and storage", Phytoplankton manual, A. A. Sournia, 69-74, United Nations Educational, Scientific and Cultural Organization, Paris, 1978.

30. C. R. Tomas, "Identifying Marine Phytoplankton", 858, Academic Press, New York, USA, 1997.

31. Gordon H R \& Wang M, Retrieval of water leaving radiance and aerosol optical thickness over the oceans with SeaWiFS: A preliminary algorithm, J. App. Optics, 33 (1994) 443-452.

32. P. Chauhan, M. Mohan, S. Nayak, "Retrieval of Ocean constituents by IRS-P4 OCM" Proceedings $4^{\text {th }}$ Berlin Workshop on Remote Sensing '5 Years of MOS-IRS, DLR, Berlin, 2001,

33. J. E. O’Reilly, S. Maritonena, B. G. Mitchell, D. A. Siegal, K L Carder, S. A. Graver, M. Kahru, C. R. McClain, "Ocean color chlorophyll algorithms for SeaWiFS", Journal of Geophysics Research, 103, 24937$24963,1998$. 
Table 1 Chlorophyll $a$ at surface and column

\begin{tabular}{|l|c|c|c|c|c|c|}
\hline \multirow{2}{*}{ Months } & \multicolumn{3}{|c|}{$\begin{array}{c}\text { Surface Chl } \\
\left(\mathbf{m g m}^{-3}\right)\end{array}$} & \multicolumn{3}{c|}{$\begin{array}{c}\text { Column Chl } a \\
\left(\mathbf{m g m}^{-2}\right)\end{array}$} \\
\cline { 2 - 7 } & Min & Max & Aver & Min & Max & Aver \\
\hline $\begin{array}{l}\text { Nov } \\
(\mathrm{n}=13)\end{array}$ & 0.173 & 5.344 & 0.726 & 8.621 & 146.426 & 43.812 \\
\hline $\begin{array}{l}\text { Dec } \\
(\mathrm{n}=14)\end{array}$ & 0.190 & 0.510 & 0.340 & 18.39 & 27.24 & 22.140 \\
\hline $\begin{array}{l}\text { Jan } \\
(\mathrm{n}=25)\end{array}$ & 0.173 & 2.6 & 0.723 & 1.743 & 322.525 & 44.529 \\
\hline $\begin{array}{l}\text { Feb } \\
(\mathrm{n}=10)\end{array}$ & 0.132 & 0.960 & 0.344 & 3.292 & 49.383 & 17.366 \\
\hline $\begin{array}{l}\text { March } \\
(\mathrm{n}=13)\end{array}$ & 0.169 & 2.741 & 0.963 & 1.605 & 338.975 & 62.842 \\
\hline $\begin{array}{l}\text { April } \\
(\mathrm{n}=35)\end{array}$ & 0.074 & 5.905 & 0.665 & 3.337 & 64.126 & 14.001 \\
\hline
\end{tabular}

Table 2 Primary productivity at surface and column

\begin{tabular}{|c|c|c|c|c|c|c|}
\hline \multirow{2}{*}{ Months } & \multicolumn{3}{|c|}{$\begin{array}{c}\text { Surface PP } \\
\left(\mathbf{m g C m}^{-3} \mathbf{d}^{-\mathbf{1}}\right)\end{array}$} & \multicolumn{3}{c|}{$\begin{array}{c}\text { Column PP } \\
\left(\mathbf{m g C m}^{-2} \mathbf{d}^{-\mathbf{1}}\right)\end{array}$} \\
\cline { 2 - 7 } & Min & Max & Aver & Min & Max & Aver \\
\hline $\begin{array}{c}\text { Nov } \\
(\mathrm{n}=13)\end{array}$ & 0.953 & 20.457 & 8.460 & 7.808 & 42.267 & 21.139 \\
\hline $\begin{array}{c}\text { Dec } \\
(\mathrm{n}=12)\end{array}$ & 55.85 & 706.66 & 314.68 & 1299 & 15442.57 & 7343.33 \\
\hline $\begin{array}{c}\text { Jan } \\
(\mathrm{n}=13)\end{array}$ & 0.907 & 2572.194 & 226.098 & 182.195 & 26906.72 & 3356.701 \\
\hline $\begin{array}{c}\text { Feb } \\
(\mathrm{n}=6)\end{array}$ & 1.724 & 12.528 & 5.406 & 93.168 & 389.543 & 219.096 \\
\hline $\begin{array}{c}\text { March } \\
(\mathrm{n}=10)\end{array}$ & 1.056 & 19.775 & 9.093 & 93.033 & 872.025 & 436.578 \\
\hline $\begin{array}{c}\text { April } \\
(\mathrm{n}=24)\end{array}$ & 5.441 & 3489.104 & 367.982 & 100.131 & 17414.98 & 2711.610 \\
\hline
\end{tabular}


Table 3 Dominant phytoplankton species in the NE Arabian Sea

\begin{tabular}{|c|l|l|l|l|l|l|}
\hline \multirow{2}{*}{ Months } & \multicolumn{5}{|c|}{ Dominant phytoplankton species } \\
\cline { 2 - 7 } & \multicolumn{5}{|c|}{ Surface } & \multicolumn{3}{c|}{ Column } \\
\hline Nov & $\begin{array}{l}\text { Trichodesmium } \\
\text { thiebautii }\end{array}$ & $\begin{array}{l}\text { Nitzschia } \\
\text { closterium }\end{array}$ & $\begin{array}{l}\text { Ampphora } \\
\text { hyalina }\end{array}$ & $\begin{array}{l}\text { Chaetoceros } \\
\text { socilalis }\end{array}$ & $\begin{array}{l}\text { Melosira } \\
\text { moniliformis }\end{array}$ & $\begin{array}{l}\text { Chaetoceros } \\
\text { danicus }\end{array}$ \\
\hline Dec & $\begin{array}{l}\text { Gymnodinium } \\
\text { gracile }\end{array}$ & $\begin{array}{l}\text { Prorocentrum } \\
\text { minimus }\end{array}$ & $\begin{array}{l}\text { Rhizosolenia } \\
\text { alata }\end{array}$ & $\begin{array}{l}\text { Trichodesmium } \\
\text { thiebautii }\end{array}$ & $\begin{array}{l}\text { Nitzschia } \\
\text { longissima }\end{array}$ & $\begin{array}{l}\text { Actinoptych } \\
\text { us senarius }\end{array}$ \\
\hline Jan & $\begin{array}{l}\text { Gymnodinium } \\
\text { breve }\end{array}$ & $\begin{array}{l}\text { Gonyaulax } \\
\text { schilleri }\end{array}$ & $\begin{array}{l}\text { Amphidinium } \\
\text { carteare }\end{array}$ & $\begin{array}{l}\text { Amphidinium } \\
\text { carteare }\end{array}$ & $\begin{array}{l}\text { Coscinodiscus } \\
\text { radiatus }\end{array}$ & $\begin{array}{l}\text { Gyrodinium } \\
\text { spirale }\end{array}$ \\
\hline Feb & $\begin{array}{l}\text { Noctiluca } \\
\text { miliaris }\end{array}$ & $\begin{array}{l}\text { Navicula sp. I } \\
\text { Mrichodesmium } \\
\text { erythraeum }\end{array}$ & $\begin{array}{l}\text { Noctiluch } \\
\text { closterium }\end{array}$ & $\begin{array}{l}\text { Noctiluca } \\
\text { miliaris }\end{array}$ & $\begin{array}{l}\text { Rhizosolenia } \\
\text { shrubsolei }\end{array}$ & $\begin{array}{l}\text { Coscinodisc } \\
\text { us occulus }\end{array}$ \\
\hline April & $\begin{array}{l}\text { Trichodesmium } \\
\text { erythraeum }\end{array}$ & $\begin{array}{l}\text { Coscinodiscus } \\
\text { marginatus }\end{array}$ & $\begin{array}{l}\text { Peridinium } \\
\text { elegans }\end{array}$ & $\begin{array}{l}\text { Rhizosolenia } \\
\text { shrubsolei }\end{array}$ & $\begin{array}{l}\text { Pyrophacus } \\
\text { horologium }\end{array}$ & $\begin{array}{l}\text { Cocconeis } \\
\text { scutellum }\end{array}$ \\
\hline
\end{tabular}

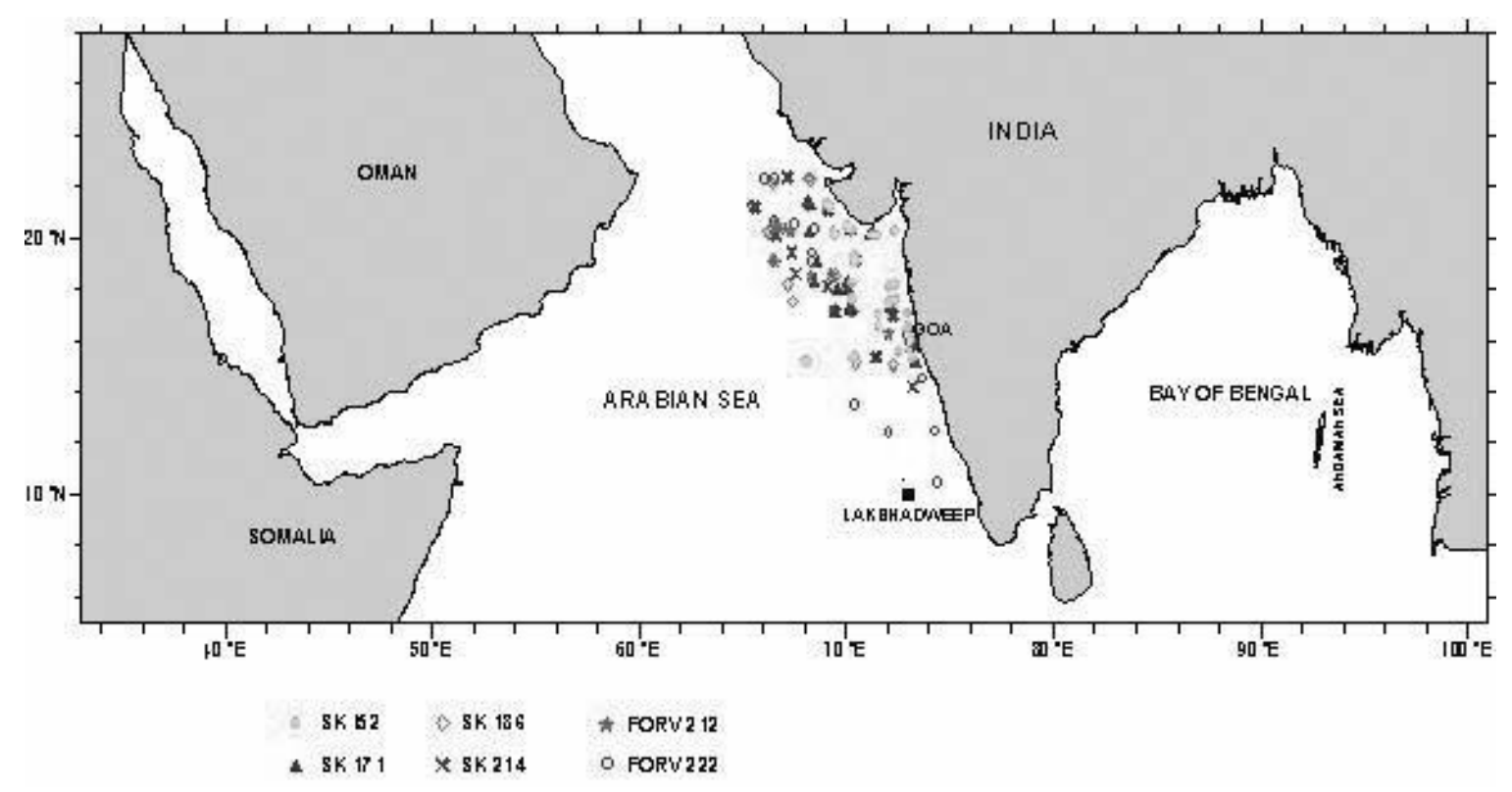

Fig. 1 Sampling stations in the Arabian Sea 

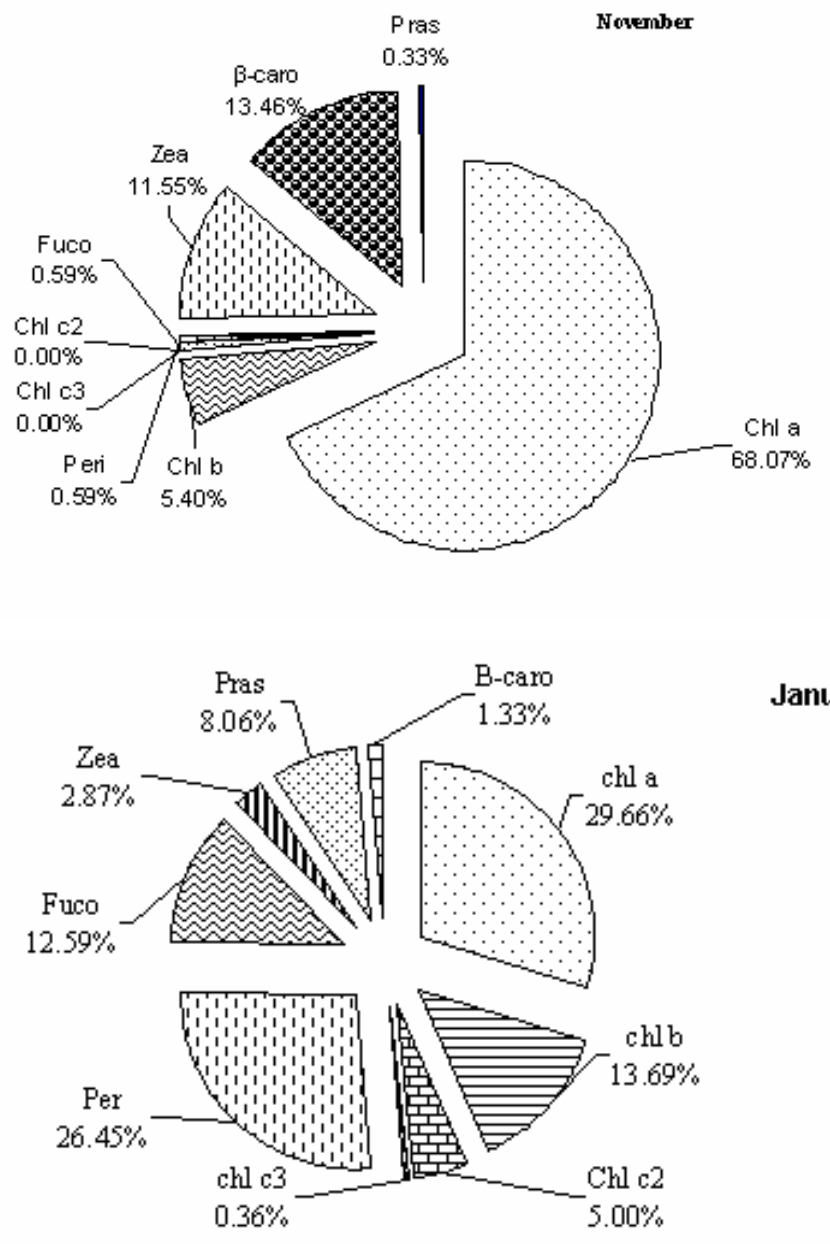

January

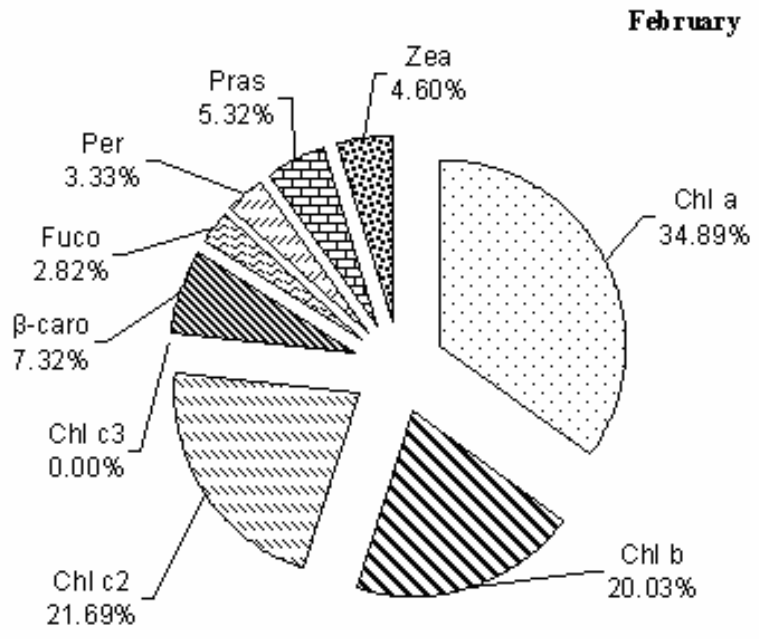

March

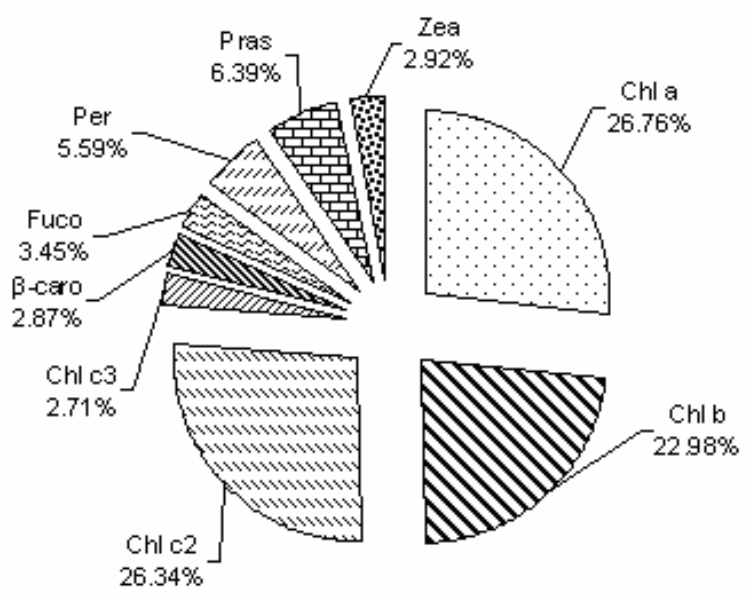

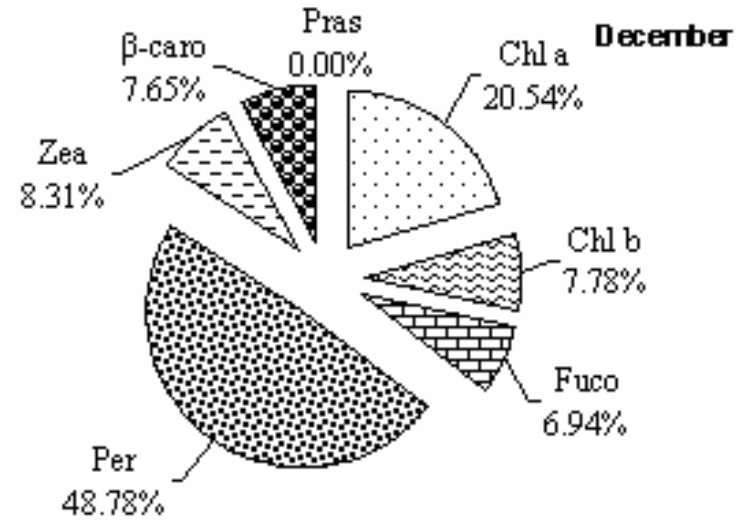

$48.78 \%$

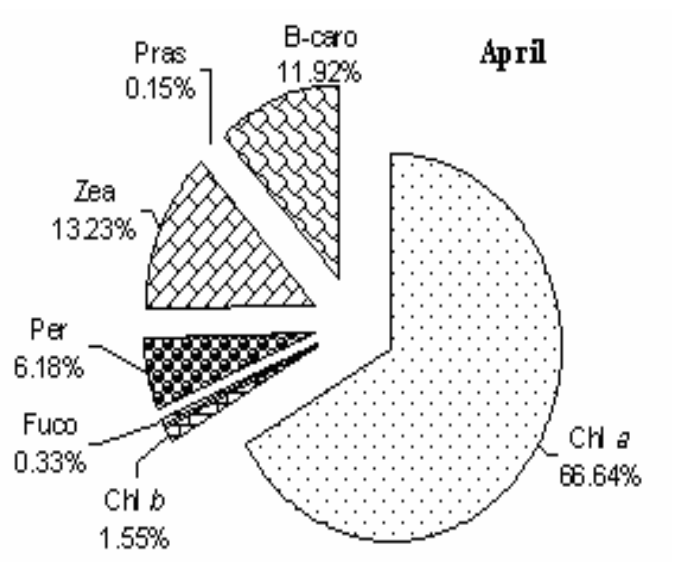

Fig 2 Distribution of pigments during different months. Chl $a$ - chlorophyll $a$; Chl $b$ - chlorophyll $b$; Chl $c$ - chlorophyll $c$; fuco fucoxanthin ; $\beta$-caro- $\beta$-carotene; per-peridinin 


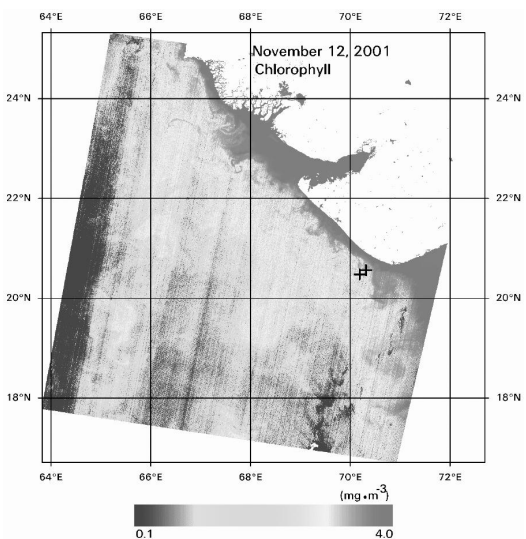

November

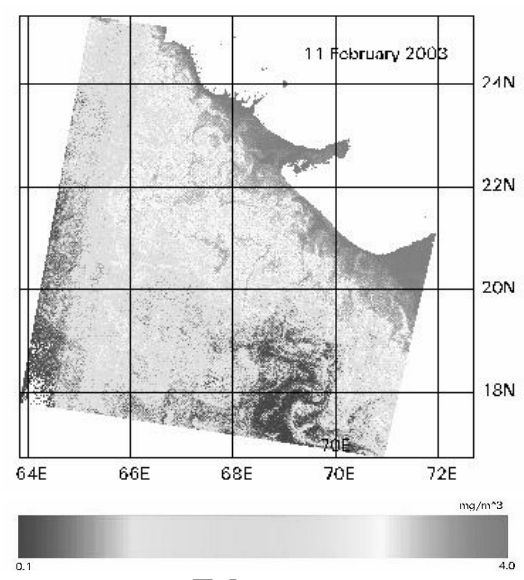

February

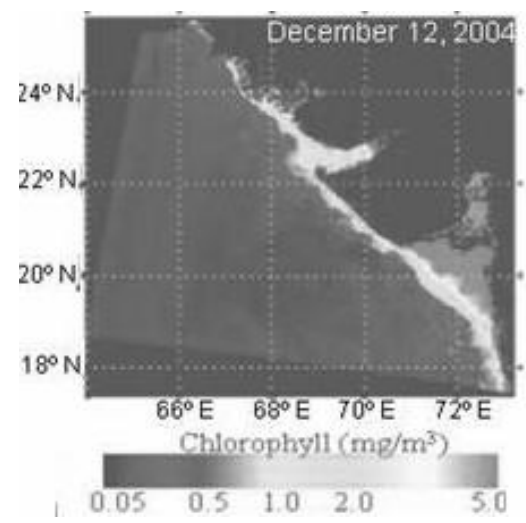

December

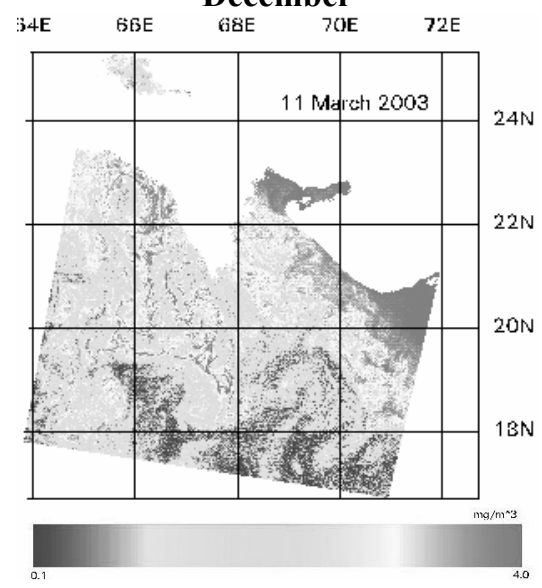

March

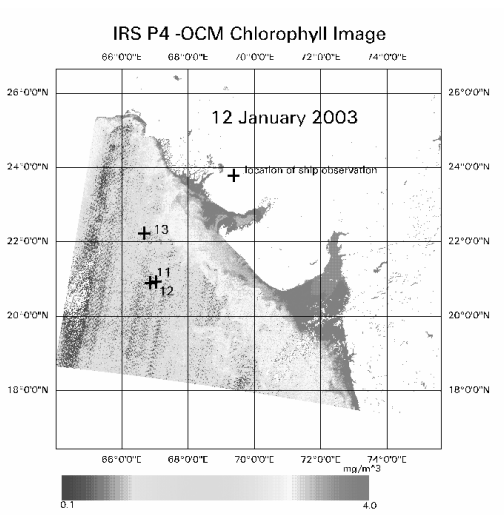

January

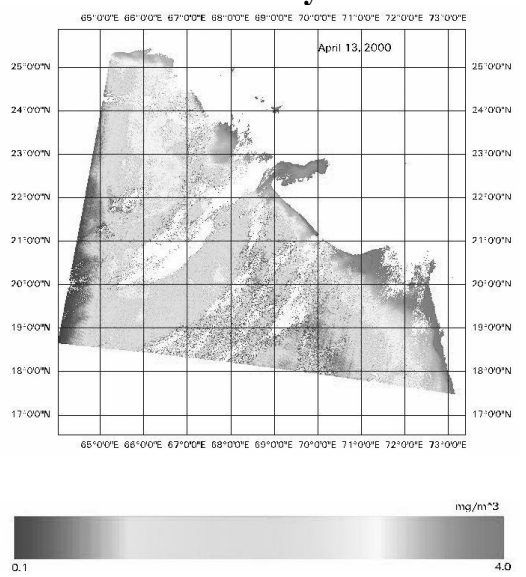

April

Fig. 3 Chlorophyll $a$ from OCM in the NE Arabian Sea during different months 